\title{
Exploration of Determinants of Verbal Aggressiveness and Leadership through Network Analysis and Conventional Statistics: Using School Class as an Illustration
}

\author{
Dimitrios Theocharis, Alexandra Bekiari, Athanasios Koustelios \\ Department of Physical Education and Sports, University of Thessaly, Thessaly, Greece \\ Email: theoj2009@gmail.com
}

How to cite this paper: Theocharis, D., Bekiari, A., \& Koustelios, A. (2017). Exploration of Determinants of Verbal Aggressiveness and Leadership through Network Analysis and Conventional Statistics: Using School Class as an Illustration. Sociology Mind, 7, 27-43.

https://doi.org/10.4236/sm.2017.72003

Received: October 19, 2016

Accepted: February 25, 2017

Published: February 28, 2017

Copyright $\odot 2017$ by authors and Scientific Research Publishing Inc. This work is licensed under the Creative Commons Attribution International License (CC BY 4.0).

http://creativecommons.org/licenses/by/4.0/

\begin{abstract}
The purpose of this study is to detect structures of verbal aggressiveness and leadership using social networks analysis. Standardized questionnaires including network and non-network variables have been distributed to 128 students and 43 teachers at secondary schools. We performed complete analysis of social networks and further processing by applying principal component analysis. According to the results, a complex structure of verbal aggressiveness occurred in the classes (networks) and the structure was necessary to be explored with several network indicators (Katz, pagerank etc.). Structures of verbal aggressiveness and leadership appeared to converge. The following types of verbal aggressors were proposed: a) the "mocker", b) the "scorner", c) the "insulter", d) the "teaser" and e) the "ridiculer". As for the leadership, two types of leaders have been revealed: a) the "ideologist leader", b) the "realist" leader. It is noticeable that both leader types appear in the occasional (indegree) as well as in the accumulative (Katz) structure. This means a rigid character of these leadership profiles.
\end{abstract}

\section{Keywords}

Verbal Aggressiveness, Leadership, Network Analysis, Typology

\section{Introduction}

\subsection{Verbal Aggressiveness}

Infante \& Wigley (1986) have defined the verbal aggressiveness as an attack in the perception of individual without, or with, simultaneous attack to the attitude that the person takes toward a communication issue. Verbal aggressiveness 
functions as a catalyst for physical aggressiveness (Infante, Chandler, \& Rudd, 1989; Infante \& Wigley, 1986; Sabourin, Infante, \& Rudd, 1993). The negative effects of verbal aggressiveness may be more disturbing even than physical aggression because its effects may last longer (Infante, 1995). The majority of research shows that the verbal aggressiveness is considered to be destructive (Bekiari, 2016; Bekiari, Kokaridas, \& Sakellariou, 2005, 2006; Bekiari, Perkos, \& Gerodimos, 2015; Infante, 1995; Myers, Edwards, Wahl, \& Martin, 2007; Myers \& Rocca, 2000). It has been found that there is a negative relationship between perceived verbal aggressiveness of the teacher with the affective learning (Bekiari, 2012; Bekiari \& Manoli, 2016; Myers \& Knox, 1999, 2000; Myers \& Rocca, 2000, 2001). It is also negatively correlated with students' motivation (Bekiari, 2014; Bekiari \& Sakellariou, 2002; Bekiari \& Syrmbas, 2015; Goodboy \& Bolkan, 2009; Myers et al., 2007; Rocca, 2004, 2008) and fair play behaviors (Hassandra, Bekiari, \& Sakellariou, 2007). Also, verbal aggressiveness affects on the discipline in class (Bekiari et al., 2006; Bekiari \& Tsiana, 2016) causing behaviours (Claus, Booth-Butterfield, \& Chory, 2012; Kennedy-Lightsey \& Myers, 2009), reducing teacher's reliability (Infante, 1985; Infante et al., 1992) and interpersonal attraction (Syrmpas \& Bekiari, 2015). Students declare lower levels of satisfaction and learning (Bekiari, 2014; Bekiari, Perkos, et al., 2015; Manoli \& Bekiari, 2015; Mazer \& Stowe, 2015; Myers, 2002; Myers et al., 2007; Myers \& Knox, 1999, 2000; Myers \& Rocca, 2001; Schrodt, 2003) and present lower academic achievement scores (Uludag, 2013; Yaratan \& Uludag, 2012). Also, verbal aggressiveness is negatively associated with interest (Weiss \& Houser, 2007), self-esteem (Buford, 2010; Infante \& Wigley, 1986; Schrodt, 2003), behaviour, thinking and motivation (Bekiari, Perkos, et al., 2015; Hasanagas \& Bekiari, 2015; Mazer \& Stowe, 2015). Verbal aggressiveness practised by instructors negatively affects the relationship with their students (Frymier \& Wanzer, 2006; Manoli \& Bekiari, 2015; Martin \& Myers, 2006) or athletes in training context (Bekiari, Digelidis, \& Sakellariou, 2006; Bekiari, Patsiaouras, Kokaridas, \& Sakellariou, 2006). The use of verbal aggressiveness by teachers has adverse effects for themselves, as they appear to be less communicative (Myers et al., 2007). Students present a less scientific approach and sociability (Hasanagas \& Bekiari, 2015; Myers \& Rocca, 2000; Rocca \& McCroskey, 1999) while they report burnout (Avtgis \& Rancer, 2008; Yaratan \& Uludag, 2012). Instead, the lack of verbal aggressiveness enhances motivation, positive perception of classroom climate and emotional learning (Mazer \& Stowe, 2015). Several studies describe the negative effects of using verbal aggressiveness from their chiefs to subordinates at the workplace (Infante, Anderson, Martin, Herington, \& Kim, 1993; Infante \& Gorden, 1985a, 1985b; Wheeless, Wheeless, \& Howard, 1984) but few are those who associate the verbal aggressiveness with the leadership.

\subsection{Leadership}

Research on leadership mainly focuses on transformational leaders who could change deep structures, major procedures or the overall organisation (Van Wart, 
2003). Bass (1985) model examines the relationship between transactional and transformational leadership. Transactional leadership based on a relation transaction between directors and members/employees, promoting them with rewards (Burns, 1978; Pashiardis, 2004). It consists in an administration of minimal interventions (laissez-faire), based on the exceptions management (management by exception) and contingent reward (Robbins \& Judge, 2012). In contrast, transformational leadership is a special leadership style applied by superiors to motivate subordinates to operate at a higher level, offering spiritual challenges and paying attention to their individual needs by creating a supportive environment (Belias \& Koustelios, 2014; Gkolia, Belias, \& Koustelios, 2014b). Transformational leadership is based on trust and respect, engaging a parallel commitment to a vision creating incentives for employees (Eliophotou-Menon, 2011). The transformational leadership is grounded on the following characteristics: idealized influence, inspirational motivation, intellectual stimulation and personalized care (individualized consideration) (Bass, 1991, 1999; Bass \& Stogdill, 1990; Robbins \& Judge, 2012). According to the afore-mentioned assumptions, leadership can be regarded as process influencing thought, emotions, attitudes, and behaviours of a group of people from the leader. In this process, the led members are supposed to willingly and appropriately cooperate in order to achieve their best performance (Bouradas, 2005).

Aim of this research is to suggest determinants and effects of verbal aggressiveness and leadership, measured in term of its effect, leadership, as well as to analyze relations between leadership and verbal aggressiveness. The expected innovation lies in the implementation of complete network analysis which is expected to depict more objectively the structures of leadership and verbal aggressiveness.

\section{Method}

\subsection{Network Analysis}

Complete network analysis focuses on the interaction of participants and uses a set of metrics for the analysis of their relationships (Scott, 2000; Wasserman \& Faust, 1994). The following network analysis metrics have been calculated by Visone software:

1) In-degree is defined as the percentage of edges which ends in a node. It can be interpreted as an occasional hierarchy position.

2) Katz status expresses chains of successive relations using power series. Thus, it can be interpreted as an accumulative hierarchy position. It signifies situations much deeper than indegree.

3) Pagerank is based on the transferred value from one node to others and interpreted as distributive hierarchy position. It is similar to Katz status but it restricts outliers. Furthermore, it prevents hierarchy deformations induced by Katz status.

4) Authority indicates the nodes who attracting most links from other nodes, among those ones who intensively seek to maintain links. 
All aforementioned metrics have been repeatedly used and interpreted in real-empirical context (Bekiari, Hasanagas, Theocharis, Kefalas, \& Vasilou, 2015; Bekiari \& Hasanagas, 2015, 2016a, 2016b; Bekiari \& Spyropoulou, 2016; Hasanagas \& Bekiari, 2015; Theocharis \& Bekiari, 2016).

\subsection{Sampling}

Classes of public secondary schools (Gymnasium and Lyceum) in Trikala have been surveyed as network samples. Each class consisted a network, where the pupils were the nodes and the links among them were their relations (trust, company, conflicts etc). In other words, such a network sampling is a cluster sampling including the survey of links among the population (Farmakis, 2000). The set was calculated to be composed by 171 individuals. There were 128 pupils (class A: 20 pupils, female: 5 male: 15, class B: 21 pupils, female: 10 male: 11, class C: 22 pupils, female: 8 , male: 14 , class D: 21 pupils, female: 10 male: 11 , class E: 21 pupils, female: 8 male: 13, class F: 24 pupils, female: 15 male: 9). Their age varied from 13 to 17 . Also, there were 43 teachers (female: 22, male: 21). Their age varied from 32 to 62 . Precondition to participate a teacher was to teach over two hours per week in the class involved in the research.

\subsection{Questionnaire}

The questionnaire consisted of two parts: a) non-network variables (e.g. gender, birth year, teaching years etc.), and b) network variables (power dimensions, verbal aggressiveness and leadership).

The part $\mathrm{b}$ of the questionnaire was based on the Verbal Aggressiveness Scale (Bekiari \& Digelidis, 2015) in order to measure verbal aggressiveness. Preliminary examination Scale (Bekiari \& Digelidis, 2015) supported the psychometric properties of the instrument. In particular, confirmatory factor analysis indicated satisfactory fit indices (CFI: .97, SRMR: .02), and internal consistency of the scale $(\alpha=.96)$. The scale consisted of eight items (e.g., "insults students or teachers," "makes negative judgments of ability").

The part $b$ of the questionnaire was based on the Principal Leadership Questionnaire which consisted of twenty four items (Gkolia, Belias, \& Koustelios, 2014a) in order to measure transformational leadership. Preliminary examination supported the psychometric properties of the instrument. In particular, confirmatory factor analysis indicated satisfactory fit indices $(\mathrm{CFI}=.97$, RMSEA $=.06)$, and internal consistency of the scale ( $\alpha$ : from .60 to .81 ). The scale consisted of four factors (leader models behavior, fosters commitment, provides individual support, and holds high expectations) (e.g. "treats me as an individual with unique needs", "leads by 'doing' rather than simply by 'telling')".

Additional questions of the power dimensions (part $\mathrm{b}$ of the questionnaire) concerning trust (e.g., advising about humanities and natural Sciences), socialization patterns (e.g., companion within and outside faculty) and study and general cooperation. The power dimensions based on Popitz model (1992) has been used in previous researches (Bekiari \& Hasanagas, 2015, 2016a, 2016d; Bekiari \& Spyropoulou, 2016; Hasanagas \& Bekiari, 2015). 


\subsection{Statistical Analysis}

The network data were processed by Visone 2.16 software. Several indicators were computed (indegree, status, pagerank, authority, density). Also, different networks structure was depicted.

Thereafter, both the network and non-network data were entered into SPSS 21. Spearman bivariate correlation (to avoid outlier effect) and principal components analysis (for formulating typology) were conducted.

\section{Results and Discussion}

\subsection{Examples of Structures in Verbal Aggressiveness and Leadership}

In Figures 1-3 several structures (status of Katz, pagerank and authority) of verbal aggressiveness and leadership are presented. Differences can be observed between the structures of verbal aggressiveness and leadership networks. The networks do not have the same density and networks of leadership are denser than those of verbal aggressiveness. Density was the measure depicting the intensity of the relations between individuals in classes. Density can be utilized as a measure of cohesion, at least 0 case of non-conflicting relations (Borgatti, Everett, \& Johnson, 2013) and has been used to examine leadership relations in classes (Carson, Tesluk, \& Marrone, 2007). More specifically, the density of each network is the portion of the potential connections in a network that the
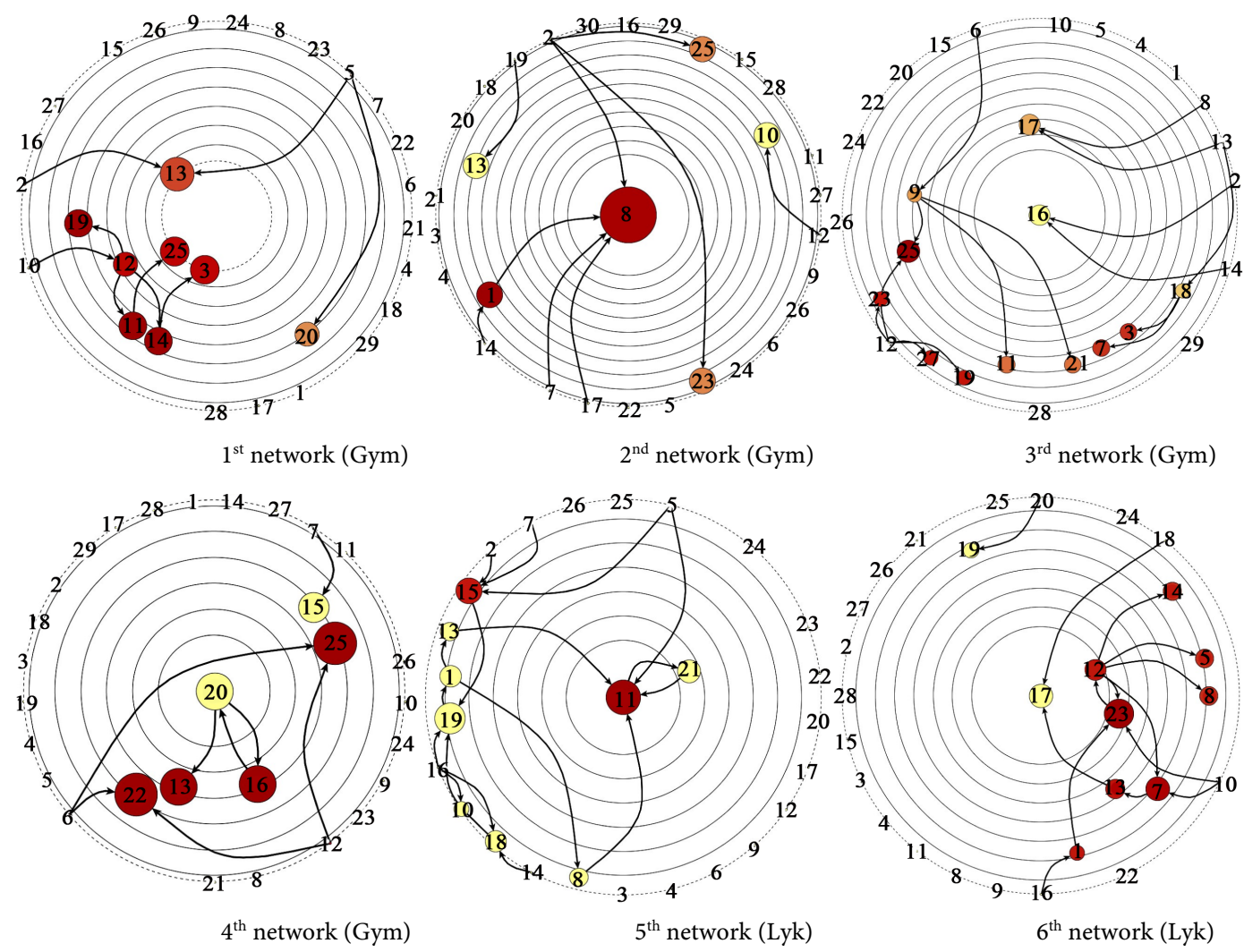

Figure 1. Structure of verbal aggression (negative comments). 

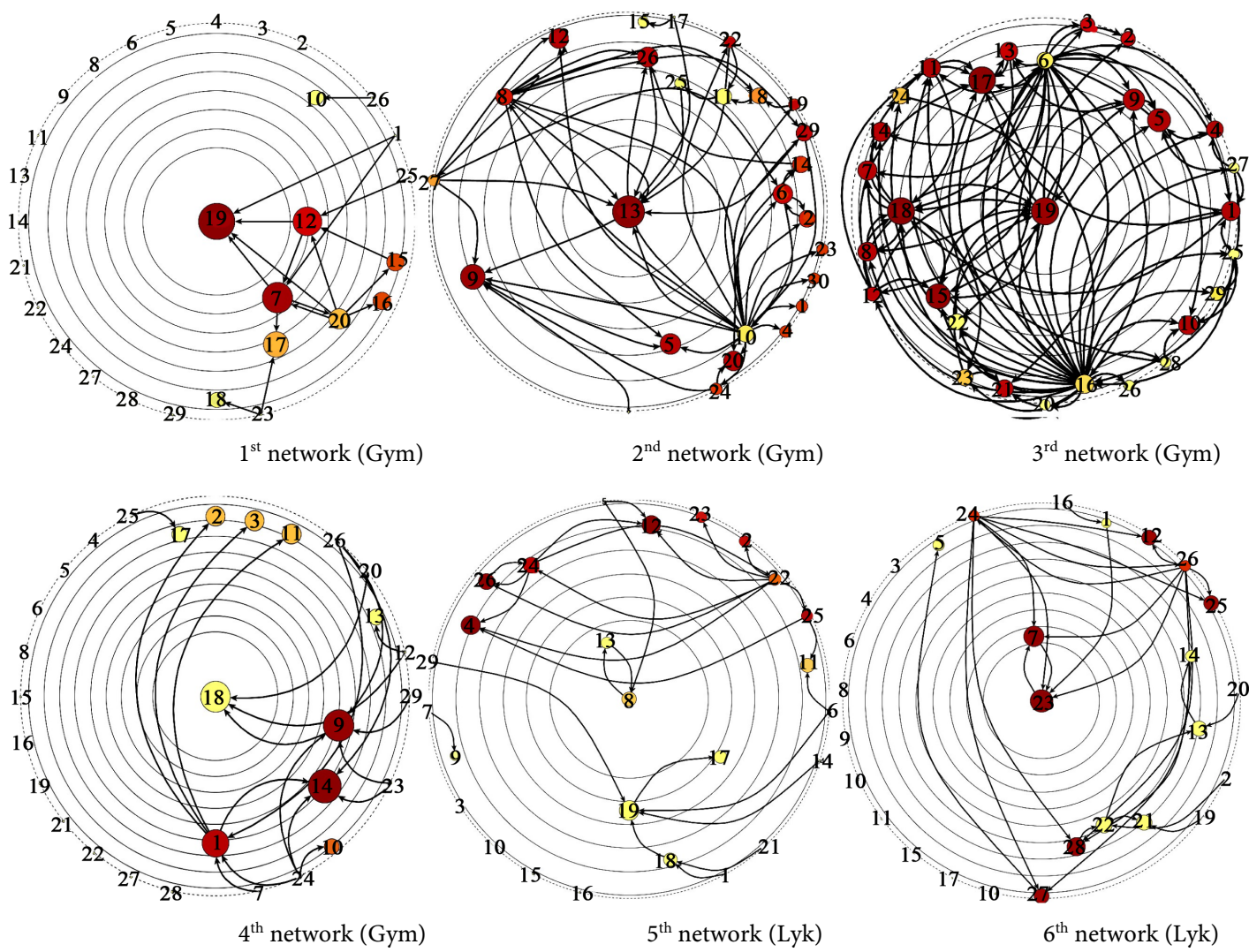

Figure 2. Structure of leadership (leader act).
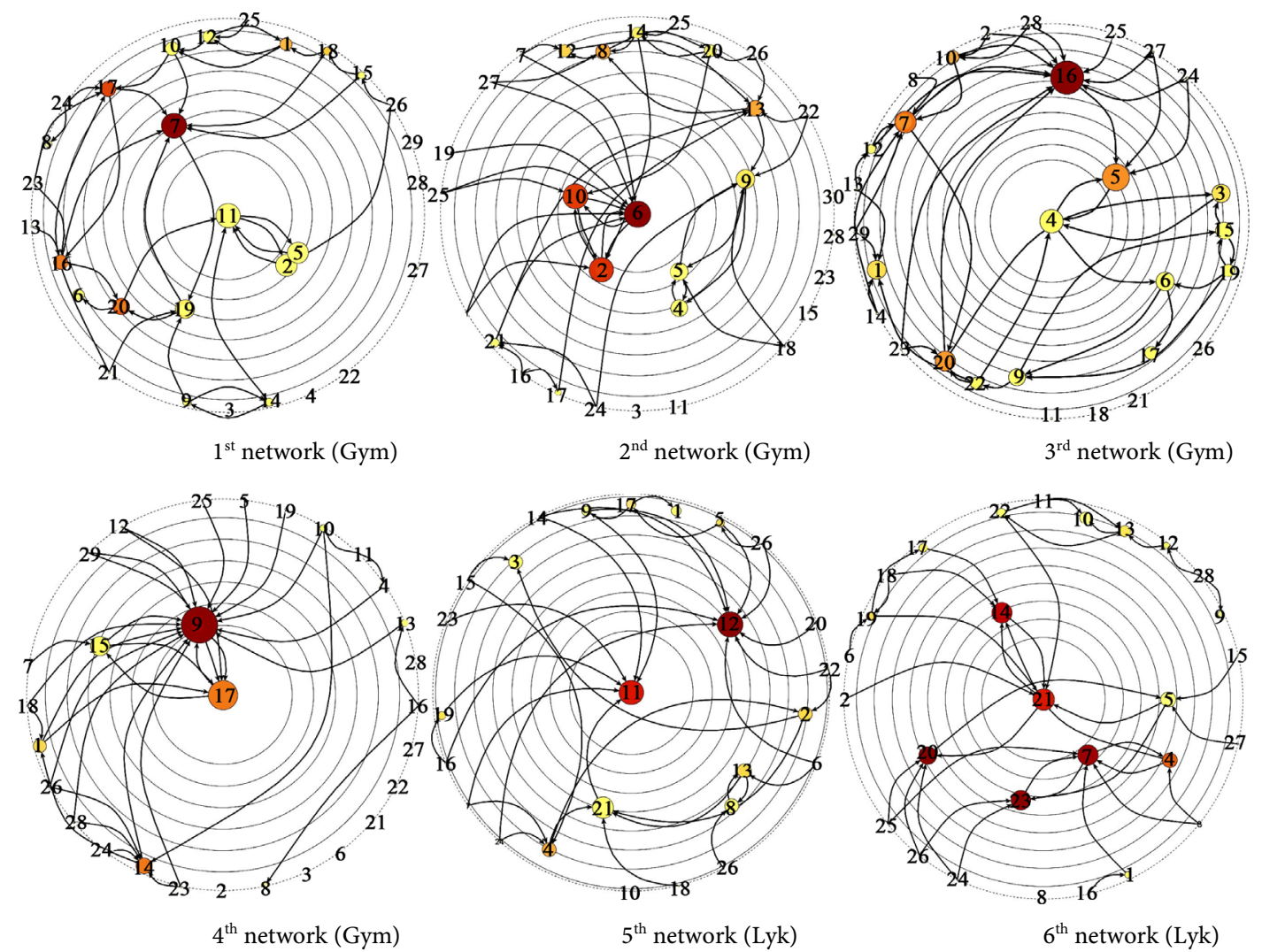

Figure 3. Structure of the preferred class president. 
actual connections (Sparrowe, Liden, Wayne, \& Kraimer, 2001). The observed conclusion can be confirmed and as shown in the Table 1 , the average density of verbal aggression was .030 while leadership has average density .090 and the proposed as president was .091. Additionally, the average indegree-outdegree of leadership networks was bigger than verbal aggression one as shown in Table 2.

Additionally, differences can be observed in the networks observing various indicators (pagerank, status, authority etc.). These differences were expected because various indicators reveal no identical properties and meanings. So, it is useful to apply several indicators in social network analysis and not only one (Bekiari \& Hasanagas, 2015).

\subsection{Relationship between Verbal Aggressiveness, Leadership Characteristics and Preferred Class President}

In Table 3 it is noticeable that numerous significant correlations occur between preferred class president and leader characteristics (.230 to .564) or of verbal aggressiveness attributes (.174 to .303) or of social interactions (.268 to .370).

All leadership variables were significant correlated with the property of being preferred for president. The results showed a positive correlation between this property and the various characteristics of leadership (leader acts, leader is an example, does not believe in mediocrity, personal approach and communication). No significant correlation had been found between the property of being preferred president and "have high expectations of a leader". This can be explained by the nature of the position of the class president. It is sure that anyone of classmates expects the president to be the most capable but also knows the limitation of the position, so they don't have high expectation from him. Also, all

Table 1. Density of six networks (computed by Visone 2.16).

\begin{tabular}{|c|c|c|c|c|c|c|c|c|}
\hline & $\begin{array}{c}\text { 1st } \\
\text { network }\end{array}$ & $\begin{array}{l}\text { 2nd } \\
\text { network }\end{array}$ & $\begin{array}{c}\text { 3rd } \\
\text { network }\end{array}$ & $\begin{array}{l}\text { 4th } \\
\text { network }\end{array}$ & $\begin{array}{l}\text { 5th } \\
\text { network }\end{array}$ & $\begin{array}{c}\text { 6th } \\
\text { network }\end{array}$ & Mean & Std. Deviation \\
\hline $\begin{array}{l}\text { Verbal aggressiveness } \\
\text { (negative comments) }\end{array}$ & .022 & .021 & .037 & .017 & .049 & .034 & .030 & .01 \\
\hline Leadership (leader act) & .039 & .11 & .204 & .049 & .074 & .066 & .090 & .06 \\
\hline Preferred class president & .081 & .087 & .101 & .079 & .105 & .09 & .091 & .01 \\
\hline
\end{tabular}

Table 2. Average in-out degree of six networks (computed by Visone 2.16).

\begin{tabular}{|c|c|c|c|c|c|c|c|c|}
\hline & $\begin{array}{c}\text { 1st } \\
\text { network }\end{array}$ & $\begin{array}{c}2^{\text {nd }} \\
\text { network }\end{array}$ & $\begin{array}{c}\text { 3rd } \\
\text { network }\end{array}$ & $\begin{array}{c}\text { 4th } \\
\text { network }\end{array}$ & $\begin{array}{c}\text { 5th } \\
\text { network }\end{array}$ & $\begin{array}{c}\text { 6th } \\
\text { network }\end{array}$ & Mean & $\begin{array}{c}\text { Std. } \\
\text { Deviation }\end{array}$ \\
\hline $\begin{array}{l}\text { Verbal aggressiveness } \\
\text { (negative comments) }\end{array}$ & .31 & .3 & .517 & .276 & .654 & .5 & .426 & .15 \\
\hline Leadership (leader act) & .586 & 1.733 & 3.103 & .69 & 1.038 & .964 & 1.352 & .95 \\
\hline Preferred class president & 1.345 & 1.433 & 1.483 & 1.172 & 1.346 & 1.357 & 1.154 & .51 \\
\hline
\end{tabular}


Table 3. Table of correlations.

\begin{tabular}{|c|c|c|c|c|}
\hline \multirow{2}{*}{ Spearman's rho } & \multicolumn{4}{|c|}{ Preferred for President } \\
\hline & indegree & pagerank & status & authority \\
\hline \multirow{2}{*}{ Consociation } & $.565^{\star *}$ & $.432^{* *}$ & $.555^{* *}$ & $.470^{* *}$ \\
\hline & .000 & .000 & .000 & .000 \\
\hline \multirow{2}{*}{ Cooperation } & $.634^{* *}$ & $.528^{* *}$ & $.627^{* *}$ & $.489^{* *}$ \\
\hline & .000 & .000 & .000 & .000 \\
\hline \multirow{2}{*}{ Future business relation } & $.599^{* *}$ & $.479 * *$ & $.561^{* *}$ & $.410^{* *}$ \\
\hline & .000 & .000 & .000 & .000 \\
\hline \multirow{2}{*}{ Ask help for social matters } & $.408^{\star *}$ & $.326^{* *}$ & $.375^{* *}$ & $.312^{\star *}$ \\
\hline & .000 & .000 & .000 & .000 \\
\hline \multirow{2}{*}{ Ask help for technical issues } & $.316^{* *}$ & $.268^{* *}$ & $.287^{* *}$ & $.337^{\star *}$ \\
\hline & .000 & .000 & .000 & .000 \\
\hline \multirow{2}{*}{$\begin{array}{l}\text { Verbal Aggressiveness } \\
\text { (negative comments about spirit) }\end{array}$} & $.207^{\star *}$ & .114 & $.204^{* *}$ & $.175^{*}$ \\
\hline & .007 & .138 & .007 & .022 \\
\hline \multirow{2}{*}{$\begin{array}{c}\text { Verbal Aggressiveness } \\
\text { (negative comments about behavior) }\end{array}$} & .148 & .079 & $.151^{*}$ & $.175^{*}$ \\
\hline & .054 & .302 & .049 & .022 \\
\hline \multirow{2}{*}{$\begin{array}{c}\text { Verbal Aggressiveness } \\
\text { (negative comments about appearance) }\end{array}$} & .115 & .027 & .114 & .100 \\
\hline & .134 & .726 & .137 & .191 \\
\hline \multirow{2}{*}{$\begin{array}{l}\text { Verbal Aggressiveness } \\
\text { (negative comments about surroundings) }\end{array}$} & $.232^{\star *}$ & .146 & $.212^{* *}$ & .124 \\
\hline & .002 & .056 & .005 & .107 \\
\hline \multirow{2}{*}{$\begin{array}{l}\text { Verbal Aggressiveness } \\
\text { (negative comments) }\end{array}$} & $.169^{*}$ & .109 & $.174^{*}$ & -.010 \\
\hline & .028 & .155 & .023 & .895 \\
\hline \multirow{2}{*}{ Verbal Aggressiveness (mockery) } & $.271^{\star *}$ & $.249^{* *}$ & $.303^{* *}$ & $.173^{*}$ \\
\hline & .000 & .001 & .000 & .024 \\
\hline \multirow{2}{*}{ Verbal Aggressiveness (threat) } & $.165^{*}$ & $.343^{* *}$ & $.179^{*}$ & $.217^{* *}$ \\
\hline & .031 & .000 & .019 & .004 \\
\hline Verbal Aggressiveness & $.265^{\star *}$ & $.288^{* *}$ & $.283^{* *}$ & $.270^{\star *}$ \\
\hline (belief of expressing negative comments) & .000 & .000 & .000 & .000 \\
\hline Verbal Aggressiveness & $.282^{* *}$ & $.332^{* *}$ & $.305^{* *}$ & $.348^{* *}$ \\
\hline (don't want you in his social surrounding) & .000 & .000 & .000 & .000 \\
\hline \multirow{2}{*}{ Afraid of being hit } & $.166^{*}$ & $.364^{* *}$ & $.187^{*}$ & $.218^{* *}$ \\
\hline & .031 & .000 & .014 & .004 \\
\hline \multirow{2}{*}{ Leadership (leader act) } & $.429^{* *}$ & $.378^{* *}$ & $.402^{* *}$ & $.312^{\star *}$ \\
\hline & .000 & .000 & .000 & .000 \\
\hline Leadership & $.344^{* *}$ & $.230^{* *}$ & $.327^{* *}$ & $.281^{\star *}$ \\
\hline (leader is an example) & -.103 & .002 & .000 & -.122 \\
\hline Leadership & .182 & .027 & -.115 & .111 \\
\hline (have high expectation from leader ) & .123 & .721 & .136 & .363 \\
\hline Leadership & $.461^{* *}$ & $.272^{* *}$ & $.440^{* *}$ & $.297^{\star *}$ \\
\hline (leader do not compromise with mediocrity) & .000 & .000 & .000 & .000 \\
\hline Leadership & $.230^{* *}$ & $.174^{*}$ & $.234^{* *}$ & $.247^{* *}$ \\
\hline (leader treat me special) & .002 & .023 & .002 & .001 \\
\hline Leadership & $.563^{* *}$ & $.384^{* *}$ & $.564^{* *}$ & $.416^{* *}$ \\
\hline (leader consider my opinion) & .000 & .000 & .000 & .000 \\
\hline
\end{tabular}

**. Correlation is significant at the 0.01 level (2-tailed). *. Correlation is significant at the 0.05 level (2-tailed). 
other characteristics of power were significant correlated with the preferred class president. The cooperation, the socialization, possible future business cooperation, advisory on social matters or technical themes is positive correlated with the preference of pupils for the class president. Also, the property of being preferred for class president is positive correlated with some verbal aggression variables. If someone has threatened a classmate or keeps him out of his social surrounding he creates a profile of detached person. This profile can be enforced if the person believes that the other one use negative comments for him in his surroundings. Additionally, the use of verbal aggression in run around situations is positive correlated with the preference of class president. This can be explained as a result of the fact that pupils use verbal aggression as a technique for choosing someone from their friends as a president.

\subsection{Target Typology of Verbal Aggressiveness and Leadership}

\subsubsection{Typology of Verbal Aggressiveness Based on Indegree Indicator}

Table 4 shows the factor loadings after rotation. The same components suggest that the type "mocker" represents verbal aggressive pupils that making negative comments and mock with their classmates. The "insulter" type depicts pupils who do not simply mock or comment other pupils but threaten and exclude their classmates from their social milieu. The "insulter" could be regarded as an aggressive type stronger and more threatening than "mocker". Both types are based on indegree. Thus, they express an occasional situation.

\subsubsection{Typology of Verbal Aggressiveness Based on Pagerank Indicator}

Table 5 shows the factor loadings after rotation. The types appearing in this table are quite similar with these revealed in Table 4. "Mockers" want to cause

Table 4. Indegree typology of verbal aggressiveness.

\begin{tabular}{|c|c|c|}
\hline \multicolumn{3}{|l|}{ Rotated Component Matrix ${ }^{a}$} \\
\hline \multirow{2}{*}{ INDEGREE } & \multicolumn{2}{|c|}{ Component } \\
\hline & Mocker & Insulter \\
\hline Verbal Aggressiveness (negative comments about spirit) & .704 & .388 \\
\hline Verbal Aggressiveness (negative comments about behavior) & .736 & .005 \\
\hline Verbal Aggressiveness (negative comments about appearance) & .653 & .306 \\
\hline Verbal Aggressiveness (negative comments about surroundings) & .746 & .195 \\
\hline Verbal Aggressiveness (negative comments) & .652 & .492 \\
\hline Verbal Aggressiveness (mockery) & .661 & .272 \\
\hline Verbal Aggressiveness (threat) & .147 & .837 \\
\hline Verbal Aggressiveness (do you believe that you express negative comments) & .220 & .824 \\
\hline Verbal Aggressiveness (don't want you in his social surrounding) & .186 & .454 \\
\hline
\end{tabular}

Extraction Method: Principal Component Analysis. Rotation Method: Varimax with Kaiser Normalization. ${ }^{a}$ Rotation converged in 3 iterations. 
Table 5. Pagerank typoplogy of verbal aggressiveness.

\begin{tabular}{ccc}
\hline Rotated Component Matrix & & \\
\hline Pagerank & \multicolumn{2}{c}{ Component } \\
\cline { 2 - 4 } & Mocker & Insulter \\
\hline Verbal Aggressiveness (negative comments about spirit) & .768 & .290 \\
Verbal Aggressiveness (negative comments about behavior) & .906 & .118 \\
Verbal Aggressiveness (negative comments about appearance) & .916 & .153 \\
Verbal Aggressiveness (negative comments about surroundings) & .943 & .103 \\
Verbal Aggressiveness (negative comments) & .913 & .166 \\
Verbal Aggressiveness (mockery) & .775 & .100 \\
Verbal Aggressiveness (threat) & .461 & .606 \\
Verbal Aggressiveness (do you believe that you express negative comments) & .030 & .759 \\
Verbal Aggressiveness (don't want you in his social surrounding) & .099 & .725 \\
\hline
\end{tabular}

Extraction Method: Principal Component Analysis. Rotation Method: Varimax with Kaiser Normalization. ${ }^{a}$ Rotation converged in 3 iterations.

repeated emotional pain, distress, or annoyance to theirs' classmate using any type of comment. The "scorner" type describes schoolchildren who the victim describes them as pupils who have lack of approval for them. "Mockers" use verbal aggressiveness because they don't want someone to be to their surroundings. "Scorners" seem to be more decided to exclude others, as they do not even spend time for commenting them.

\subsubsection{Typology of Verbal Aggressiveness Based on Kantz Status Indicator}

Table 6 shows the factor loadings after rotation. The items that cluster on the same components suggest represents mockers and the second component "scorners". This could be explained because status and pagerank have quite similar structural meaning.

\subsubsection{Typology of Verbal Aggressiveness Based on Authority Indicator} Table 7 shows the factor loadings after rotation. The items that cluster on the same components suggest that first type represents verbal aggressive students named "teaser". They act cruel and criticizing their classmates with unkind way. The second type describes verbal aggressiveness students proposed to named "ridiculer". They were making harsh comments, making fun in cruel way.

This typology is authority based. Thus, these two types reveal a much more persistent structure created by a respectively fanatical activity. The "teaser" behavior simply consists in commenting while the "ridiculer" is much more active than just commenting.

\subsubsection{Typology of Leadership Based on Indegree Indicator}

Table 8 shows the factor loadings after rotation. The first factor had four parameters with high loads that denote a leader behaviour pattern but also with high 
Table 6. Katz status typology of verbal aggressiveness.

\begin{tabular}{ccc}
\hline Rotated Component Matrix & & \\
\hline Status & \multicolumn{2}{c}{ Component } \\
\cline { 2 - 4 } & Mocker & Scorner \\
\hline Verbal Aggressiveness (negative comments about spirit) & .753 & .254 \\
Verbal Aggressiveness (negative comments about behavior) & .696 & .041 \\
Verbal Aggressiveness (negative comments about appearance) & .714 & .232 \\
Verbal Aggressiveness (negative comments about surroundings) & .778 & .117 \\
Verbal Aggressiveness (negative comments) & .723 & .378 \\
Verbal Aggressiveness (mockery) & .619 & .267 \\
Verbal Aggressiveness (threat) & .259 & .767 \\
Verbal Aggressiveness (do you believe that you express negative comments) & .235 & .786 \\
Verbal Aggressiveness (don't want you in his social surrounding) & .082 & .607 \\
\hline
\end{tabular}

Extraction Method: Principal Component Analysis. Rotation Method: Varimax with Kaiser Normalization. ${ }^{\text {a}}$ Rotation converged in 3 iterations.

Table 7. Autthority typology of verbal aggressiveness.

\begin{tabular}{ccc}
\hline Rotated Component Matrix & & \\
Authority & \multicolumn{2}{c}{ Component } \\
\cline { 2 - 4 } & Teaser & Ridiculer \\
\hline Verbal Aggressiveness (negative comments about spirit) & .530 & .514 \\
Verbal Aggressiveness (negative comments about behavior) & .784 & -.013 \\
Verbal Aggressiveness (negative comments about appearance) & .705 & .203 \\
Verbal Aggressiveness (negative comments about surroundings) & .686 & .100 \\
Verbal Aggressiveness (negative comments) & .676 & .163 \\
Verbal Aggressiveness (mockery ) & .252 & .499 \\
Verbal Aggressiveness (threat) & .157 & .706 \\
Verbal Aggressiveness (do you believe that you express negative comments) & .196 & .717 \\
Verbal Aggressiveness (don't want you in his social surrounding) & -.121 & .627 \\
\hline
\end{tabular}

Extraction Method: Principal Component Analysis. Rotation Method: Varimax with Kaiser Normalization. ${ }^{a}$ Rotation converged in 3 iterations.

expectations. This factor was named "ideologue" leader. The second factor had the remaining two parameters that indicate providing personalised support from the leader. This factor was called "realist leader," after trying to take account of real possibilities and the degree of acceptance of decisions. These two leadership profiles seem to be exclusive to each other, as they do not present any common parameter. Thus, they are two absolutely different alternatives.

\subsubsection{Typology of Leadership Based on Kantz Status Indicator}

Table 9 shows the factor loadings after rotation. The factors are the same just with those of the indegree (see Table 8 ) and, therefore, are named similarly, 
Table 8. Indegree typology of leadership.

\begin{tabular}{ccc}
\hline Rotated Component Matrix & \\
\hline Indegree & \multicolumn{2}{c}{ Component } \\
\cline { 2 - 3 } & \multicolumn{2}{c}{ Ideologue leader Realist leader } \\
\hline Leads by "doing" rather than simply by "telling" & .768 & .287 \\
Provides good models for faculty members to follow & .835 & .150 \\
Shows us that there are high expectations & .558 & -.471 \\
Does not settle for second best in the performance of our work & .809 & .276 \\
Treats me as an individual with unique needs and expertise & .172 & .719 \\
Takes my opinion into consideration & .231 & .715 \\
when initiating actions that affect my work & & \\
\hline
\end{tabular}

Extraction Method: Principal Component Analysis. Rotation Method: Varimax with Kaiser Normalization. ${ }^{\text {a}}$ Rotation converged in 3 iterations.

Table 9. Status typology of leadership.

\begin{tabular}{|c|c|c|}
\hline \multicolumn{3}{|l|}{ Rotated Component Matrix ${ }^{\mathrm{a}}$} \\
\hline \multirow{2}{*}{ Status } & \multicolumn{2}{|c|}{ Component } \\
\hline & Ideologue leader & Realist leader \\
\hline Leads by "doing" rather than simply by "telling" & .734 & .380 \\
\hline Provides good models for faculty members to follow & .823 & .178 \\
\hline Shows us that there are high expectations & .561 & -.281 \\
\hline Does not settle for second best in the performance of our work & .799 & .327 \\
\hline Treats me as an individual with unique needs and expertise & .093 & .786 \\
\hline $\begin{array}{l}\text { Takes my opinion into consideration } \\
\text { when initiating actions that affect my work }\end{array}$ & .164 & .767 \\
\hline
\end{tabular}

Extraction Method: Principal Component Analysis. Rotation Method: Varimax with Kaiser Normalization. ${ }^{\text {a}}$ Rotation converged in 3 iterations.

"ideologue" and "realist" leader respectively. This means that they both are equally implemented in incidental as well as in deep-rooted leadership tactics.

\section{Conclusion}

Results of present study, regarding structures in verbal aggressiveness and leadership, indicate that pupils choose for their leader as a person which comes from their surroundings, especially those they trust and have the most of the characteristics of a transformational leader. The networks of leadership were more cohere than ones of verbal aggressiveness.

As for the verbal aggressiveness is present to our classes and the structure seems to be complicated so it is useful to apply several indicators (Katz, pagerank etc.) and not only one. Different indicators reveal different properties and meanings. The following types were proposed: a) the "mocker", b) the "scorner", c) the "insulter", d) the "teaser", and e) the "ridiculer". The using of a wide range of network metrics (indegree, Katz, pagerank, authority) reveals a re- 
spectively meticulous range of types depicting distinct structures and behaviors.

As for the leadership types ("ideologue" and "realist"), it is noticeable that they both appear in the occasional (indegree) as well as in the accumulative (Katz) structure. This means a rigid character of these profiles.

\section{References}

Avtgis, T. A., \& Rancer, A. S. (2008). The Relationship between Trait Verbal Aggressiveness and Teacher Burnout Syndrome in K-12 Teachers. Communication Research Reports, 25, 86-89. https://doi.org/10.1080/08824090701831875

Bass, B. M. (1985). Leadership and Performance beyond Expectations. New York: Free Press.

Bass, B. M. (1991). From Transactional to Transformational Leadership: Learning to Share the Vision. Organizational dynamics, 18, 19-31. https://doi.org/10.1016/0090-2616(90)90061-S

Bass, B. M. (1999). Two Decades of Research and Development in Transformational Leadership. European Journal of Work and Organizational Psychology, 8, 9-32. https://doi.org/10.1080/135943299398410

Bass, B. M., \& Stogdill, R. M. (1990). Handbook of Leadership (Vol. 11). New York: Free Press.

Bekiari, A, Patsiaouras, A., Kokaridas, D., \& Sakellariou, K. (2006). Verbal Aggressiveness and State Anxiety of Volleyball Players and Coaches. Psychological Reports, 99, 630-634. https://doi.org/10.2466/pr0.99.2.630-634

Bekiari, A., \& Manoli, P. (2016). EFL Teacher Verbal Aggressiveness and Argumentativeness and Student Socio-Affective Strategy Use and Affective Learning: Exploring Possible Associations. Journal of Teacher Education and Educators, 5, No. 2.

Bekiari, A. (2012). Perceptions of Instructor's Verbal Aggressiveness and Physical Education Students' Affective Learning. Perceptual and Motor Skills, 115, 325-335. https://doi.org/10.2466/06.11.16.PMS.115.4.325-335

Bekiari, A. (2014). Verbal Aggressiveness and Leadership Style of Sports Instructors and Their Relationship with Athletes' Intrinsic Motivation. Creative Education, 5, 114-121. https://doi.org/10.4236/ce.2014.52018

Bekiari, A. (2016). Insights into Instructors' Verbal Aggressiveness and Students' Machiavellianism through Leadership Style and Motivational Climate. European Scientific Journal, 12, 90-110. https://doi.org/10.19044/esj.2016.v12n25p90

Bekiari, A., \& Digelidis, N. (2015). Measuring Verbal Aggressiveness in Sport and Education. International Journal of Physical Education, 4, 12-21.

Bekiari, A., \& Hasanagas, N. (2016a). Suggesting Indicators of Superficiality and Purity in Verbal Aggressiveness: An Application in Adult Education Class Networks of Prison Inmates. Open Journal of Social Sciences, 4, 279-292. https://doi.org/10.4236/jss.2016.43035

Bekiari, A., \& Hasanagas, N. (2016b). Verbal Aggressiveness Exploration through Complete Social Network Analysis: Using Physical Education Students' Class as an Illustration. International Journal of Social Science Studies, 3, 30-49.

Bekiari, A., \& Hasanagas, N. (2016c). Sociological Insights in the Education System: "Unlocking” The Power Relations. Thessaloniki: Afoi Kyriakidi Editions SA.

Bekiari, A., \& Hasanagas, N. (2016d). "Educating” in Physical Education. Theoretical Approaches and Practical Inquiries. Thessaloniki: Afoi Kyriakidi Editions SA. 
Bekiari, A., \& Sakellariou, K. (2002). Perceived Instructor Verbal Aggressiveness and Student State Learning in Physical Education. Italian Journal of Sport Sciences, 1, 251256.

Bekiari, A., \& Spyropoulou, S. (2016). Exploration of Verbal Aggressiveness and Interpersonal Attraction through Social Network Analysis: Using University Physical Education Class as an Illustration. Open Journal of Social Sciences, 4, 144-155. https://doi.org/10.4236/jss.2016.46016

Bekiari, A., \& Syrmbas, I. (2015). Coaches' Verbal Aggressiveness and Motivational Climate as Predictors of Athletes' Satisfaction. Society \& Behavioural Science, 9, 318-329. https://doi.org/10.9734/bjesbs/2015/17757

Bekiari, A., \& Tsiana, I. (2016). Exploring Instructors' Verbal Aggressiveness and Students' Personal Orientations and Reasons of Discipline in Physical Education Class. Advances in Physical Education, 6, 158-168. https://doi.org/10.4236/ape.2016.63018

Bekiari, A., Digelidis, N., \& Sakellariou, K. (2006). Perceived Verbal Aggressiveness of Coaches in Volleyball and Basketball: A Preliminary Study. Perceptual and Motor Skills, 103, 526-530. https://doi.org/10.2466/pms.103.6.526-530

Bekiari, A., Hasanagas, A., Theocharis, D., Kefalas, I., \& Vasilou, I. (2015). The Role of Mathematical Object and the Educational Environment to Students' Interpersonal Relationships: An Application of Full Social Network Analysis. In Greek Mathematical Society (Ed.), Proceedings of the 32nd Congress of Greek Mathematical Society (pp. 151-163). Kastoria: GMS.

Bekiari, A., Kokaridas, D., \& Sakellariou, K. (2005). Verbal Aggressiveness of Physical Education Teachers and Students' Self-Reports of Behavior. Psychological Reports, 96, 493-498. https://doi.org/10.2466/pr0.96.2.493-498

Bekiari, A., Kokaridas, D., \& Sakellariou, K. (2006). Associations of Students' Self-Reports of Their Teachers' Verbal Aggression, Intrinsic Motivation, and Perceptions of Reasons for Discipline in Greek Physical Education Classes. Psychological Reports, 98, 451-461. https://doi.org/10.2466/pr0.98.2.451-461

Bekiari, A., Perkos, S., \& Gerodimos, V. (2015). Verbal Aggression in Basketball: Perceived Coach Use and Athlete Intrinsic and Extrinsic Motivation. Journal of Physical Education and Sport, 15, 96-102.

Belias, D., \& Koustelios, A. (2014). Leadership and Job Satisfaction-A Review. European Scientific Journal, 10, 24-46.

Borgatti, S. P., Everett, M. G., \& Johnson, J. C. (2013). Analyzing Social Networks. Thousand Oaks, CA: Sage.


Continuing Success]. Athens: Kritiki. (In Greek)

Buford, A. M. (2010). Perception Becomes Reality: Student-Teacher Relationships and Verbally Aggressive Messages. Master Thesis, Cleveland, OH: Cleveland State University.

Burns, J. (1978). Leadership. New York: Harper \& Row.

Carson, J. B., Tesluk, P. E., \& Marrone, J. A. (2007). Shared Leadership in Teams: An Investigation of Antecedent Conditions and Performance. Academy of management Journal, 50, 1217-1234. https://doi.org/10.2307/20159921

Claus, C. J., Booth-Butterfield, M., \& Chory, R. M. (2012). The Relationship between Instructor Misbehaviors and Student Antisocial Behavioral Alteration Techniques: The Roles of Instructor Attractiveness, Humor, and Relational Closeness. Communication Education, 61, 161-183. https://doi.org/10.1080/03634523.2011.647922

Eliophotou-Menon, M. (2011). Leadership Theory and Educational Outcomes: The Case 
of Distributed and Transformational Leadership. In ICSEI (Ed.), 24th International Congress for School Effectiveness and Improvement (pp. 1-15). Limassol: ICSEI.


loniki: Christodoulidis. (In Greek)

Frymier, A. B., \& Wanzer, M. B. (2006). Teacher and Student Affinity-Seeking in the Classroom In T. P. Mottet, V. P. Richmond, \& J. C. McCroskey (Eds.), Handbook of Instructional Communication: Rhetorical and Relational Perspectives (pp. 195-211). New York: Pearson.

Gkolia, A., Belias, D., \& Koustelios, A. (2014a). The Impact of Principals' Transformational Leadership on Teachers' Satisfaction: Evidence from Greece. European Journal of Business and Social Sciences, 3, 69-80.

Gkolia, A., Belias, D., \& Koustelios, A. (2014b). Teacher's Job Satisfaction and Self Efficacy: A Review. European Scientific Journal, 10, 321-342.

Goodboy, A. K., \& Bolkan, S. (2009). College Teacher Misbehaviors: Direct and Indirect Effects on Student Communication Behavior and Traditional Learning Outcomes. Western Journal of Communication, 73, 204-219. https://doi.org/10.1080/10570310902856089

Hasanagas, N., \& Bekiari, A. (2015). Depicting Determinants and Effects of Intimacy and Verbal Aggressiveness Target through Social Network Analysis. Sociology Mind, 5, 162-175. https://doi.org/10.4236/sm.2015.53015

Hassandra, M., Bekiari, A., \& Sakellariou, K. (2007). Physical Education Teacher's Verbal Aggression and Student's Fair Play Behaviors. Physical Educator, 64, 94-101.

Infante, D. A. (1985). Inducing Women to Be More Argumentative: Source Credibility Effects. Journal of Applied Communication Research, 13, 33-44. https://doi.org/10.1080/00909888509388419

Infante, D. A. (1995). Teaching Students to Understand and Control Verbal Aggression. Communication Education, 44, 51-63. https://doi.org/10.1080/03634529509378997

Infante, D. A., \& Gorden, W. I. (1985a). Benefits versus Bias: An Investigation of Argumentattveness, Gender, and Organizational Communication Outcomes. Communication Research Reports, 2, 196.

Infante, D. A., \& Gorden, W. I. (1985b). Superiors' Argumentativeness and Verbal Aggressiveness as Predictors of Subordinates' Satisfaction. Human Communication Research, 12, 117-125. https://doi.org/10.1111/j.1468-2958.1985.tb00069.x

Infante, D. A., \& Wigley, C. J. (1986). Verbal Aggressiveness: An Interpersonal Model and Measure. Communication Monographs, 53, 61-69. https://doi.org/10.1080/03637758609376126

Infante, D. A., Anderson, C. M., Martin, M. M., Herington, A. D., \& Kim, J. (1993). Subordinates' Satisfaction and Perceptions of Superiors' Compliance-Gaining Tactics, Argumentativeness, Verbal Aggressiveness, and Style. Management Communication Quarterly, 6, 307-326. https://doi.org/10.1177/0893318993006003004

Infante, D. A., Chandler, T. A., \& Rudd, J. E. (1989). Test of an Argumentative Skill Deficiency Model of Interspousal Violence. Communications Monographs, 56, 163-177. https://doi.org/10.1080/03637758909390257

Infante, D. A., Hartley, K. C., Martin, M. M., Higgins, M. A., Bruning, S. D., \& Hur, G. (1992). Initiating and Reciprocating Verbal Aggression: Effects on Credibility and Credited Valid Arguments. Communication Studies, 43, 182-190. https://doi.org/10.1080/10510979209368370

Kennedy-Lightsey, C. D., \& Myers, S. A. (2009). College Students' Use of Behavioral Alteration Techniques as a Function of Aggressive Communication. Communication 
Education, 58, 54-73. https://doi.org/10.1080/03634520802272299

Manoli, P., \& Bekiari, A. (2015). EFL Teacher Verbal Aggressiveness and Student Intrinsic Motivation and Social-Affective Strategy Use: Investigating Possible Relations. Advances in Research, 5, 1-13. https://doi.org/10.9734/AIR/2015/19692

Martin, M. M., \& Myers, S. A. (2006). Students' Communication Traits and Their Out-of-Class Communication with Their Instructors. Communication Research Reports, 23, 283-289. https://doi.org/10.1080/08824090600962599

Mazer, J. P., \& Stowe, S. A. (2015). Can Teacher Immediacy Reduce the Impact of Verbal Aggressiveness? Examining Effects on Student Outcomes and Perceptions of Teacher Credibility. Western Journal of Communication, 80, 1-17.

Myers, S. A. (2002). Perceived Aggressive Instructor Communication and Student State Motivation, Learning, and Satisfaction. Communication Reports, 15, 113-121. https://doi.org/10.1080/08934210209367758

Myers, S. A., \& Knox, R. L. (1999). Verbal Aggression in the College Classroom: Perceived Instructor Use and Student Affective Learning. Communication Quarterly, 47, 33-45. https://doi.org/10.1080/01463379909370122

Myers, S. A., \& Knox, R. L. (2000). Perceived Instructor Argumentativeness and Verbal Aggressiveness and Student Outcomes. Communication Research Reports, 17, 299-309. https://doi.org/10.1080/08824090009388777

Myers, S. A., \& Rocca, K. A. (2000). The Relationship between Perceived Instructor Communicator Style, Argumentativeness, and Verbal Aggressiveness. Communication Research Reports, 17, 1-12. https://doi.org/10.1080/08824090009388745

Myers, S. A., \& Rocca, K. A. (2001). Perceived Instructor Argumentativeness and Verbal Aggressiveness in the College Classroom: Effects on Student Perceptions of Climate, Apprehension, and State Motivation. Western Journal of Communication, 65, 113-137. https://doi.org/10.1080/10570310109374696

Myers, S. A., Edwards, C., Wahl, S. T., \& Martin, M. M. (2007). The Relationship between Perceived Instructor Aggressive Communication and College Student Involvement. Communication Education, 56, 495-508. https://doi.org/10.1080/03634520701466398

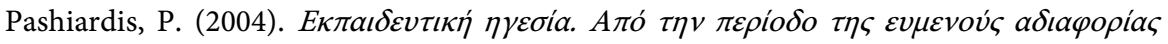

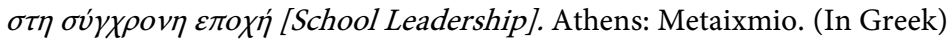

Robbins, S. P., \& Judge, T. A. (2012). Essentials of Organizational Behavior. Boston, MA: Pearson.

Rocca, K. A. (2004). College Student Attendance: Impact of Instructor Immediacy and Verbal Aggression. Communication Education, 53, 185-195. https://doi.org/10.1080/03634520410001682447

Rocca, K. A. (2008). Participation in the College Classroom: The Impact of Instructor Immediacy and Verbal Aggression. Journal of Classroom Interaction, 43, 22-33.

Rocca, K. A., \& McCroskey, J. C. (1999). The Interrelationship of Student Ratings of Instructors' Immediacy, Verbal Aggressiveness, Homophily, and Interpersonal Attraction. Communication Education, 48, 308-316. https://doi.org/10.1080/03634529909379181

Sabourin, T. C., Infante, D. A., \& Rudd, J. E. (1993). Verbal Aggression in Marriages A Comparison of Violent, Distressed but Nonviolent, and Nondistressed Couples. $\mathrm{Hu}$ man Communication Research, 20, 245-267. https://doi.org/10.1111/j.1468-2958.1993.tb00323.x

Schrodt, P. (2003). Students' Appraisals of Instructors as a Function of Students' Perceptions of Instructors' Aggressive Communication. Communication Education, 52, 106121. https://doi.org/10.1080/03634520302468 
Scott, J. (2000). Social Network Analysis: A Handbook. London: Sage.

Sparrowe, R. T., Liden, R. C., Wayne, S. J., \& Kraimer, M. L. (2001). Social Networks and the Performance of Individuals and Groups. Academy of management Journal, 44, 316-325. https://doi.org/10.2307/3069458

Syrmpas, I., \& Bekiari, A. (2015). The Relationship between Perceived Physical Education Teacher's Verbal Aggressiveness and Argumentativeness with Students' Interpersonal Attraction. Inquiries in Sport \& Physical Education, 13, 21-32.

Theocharis, D., \& Bekiari, A. (2016). Analyzing Centrality Indicators of Social Networks. Case Study on Leadership Networks of Students and Teachers. In Greek Mathematical Society (Ed.), Proceedings of the 33nd Congress of Greek Mathematical Society (pp. 250-260). Chania: GSM.

Uludag, O. (2013). The Influence of Aggression on Students' Achievement: Evidence from Higher Education. Procedia-Social and Behavioral Sciences, 89, 954-958. https://doi.org/10.1016/j.sbspro.2013.08.963

Van Wart, M. (2003). Public-Sector Leadership Theory: An Assessment. Public Administration Review, 63, 214-228. https://doi.org/10.1111/1540-6210.00281

Wasserman, S., \& Faust, K. (1994). Social Network Analysis: Methods and Applications (Vol. 8). Cambridge: Cambridge University Press. https://doi.org/10.1017/CBO9780511815478

Weiss, S. D., \& Houser, M. L. (2007). Student Communication Motives and Interpersonal Attraction toward Instructor. Communication Research Reports, 24, 215-224. https://doi.org/10.1080/08824090701439091

Wheeless, L. R., Wheeless, V. E., \& Howard, R. D. (1984). The Relationships of Communication with Supervisor and Decision-Participation to Employee Job Satisfaction. Communication Quarterly, 32, 222-232. https://doi.org/10.1080/01463378409369555

Yaratan, H., \& Uludag, O. (2012). The Impact of Verbal Aggression on Burnout: An Empirical Study on University Students. Procedia-Social and Behavioral Sciences, 46, 4146. https://doi.org/10.1016/j.sbspro.2012.05.064

Submit or recommend next manuscript to SCIRP and we will provide best service for you:

Accepting pre-submission inquiries through Email, Facebook, LinkedIn, Twitter, etc. A wide selection of journals (inclusive of 9 subjects, more than 200 journals)

Providing 24-hour high-quality service

User-friendly online submission system

Fair and swift peer-review system

Efficient typesetting and proofreading procedure

Display of the result of downloads and visits, as well as the number of cited articles

Maximum dissemination of your research work

Submit your manuscript at: http://papersubmission.scirp.org/

Or contact sm@scirp.org 